\title{
Experience marketing: a study of the conceptual aspects
}

\author{
MARIA TERESA Grimaldi LAROCCA ${ }^{1}$ \\ RODRIGO LADEIRA ${ }^{1}$ \\ ÁURIO LÚCIO LEOCÁDIO DA SILVA ${ }^{2}$ \\ RICARDO COUTINHO MELLO ${ }^{1}$ \\ 1 Universidade Federal da Bahia (UFBA) / Departamento de AdMINISTRAÇÃo, SALVAdor - BA, BrazIL \\ ${ }^{2}$ Universidade Federal do Ceará (UFC) / Departamento de Administração, Fortaleza - CE, Brazil
}

\begin{abstract}
The main objective of this study was to review the evolution and current concepts of experience marketing according to the main authors who were dedicated to the understanding of this field. The subject is part of the Marketing Science Institute Research Priorities, which points out the prevalence of studies for the marketing field. Although the subject is present in the national and international literature, there are few conceptual studies. Given the importance of the topic, this research proposes a form of understanding the phenomenon of experience marketing, exploring a conceptual approach based on the critical appreciation of concepts related to experience marketing adopting the dimensions proposed by Schmitt $(1999,2002,2006,2010)$ and the typology proposed by Lanier Junior and Rader (2015). The research considers that the level of explanatory capacity and the level of intentionality of an experiment may vary for each consumer in the same experiment. Experience marketing emerges as the new wave of contemporary marketing, and provides the most consumer loyalty and relationship, which are elements emphasized in this area of study.
\end{abstract}

Keywords: Experience marketing. Experiential marketing. Definition of experience marketing.

\section{Marketing De Experiência: um estudo dos aspectos conceituais}

\section{Resumo}

O presente estudo teve como objetivo central revisar a evolução e atuais conceitos de marketing de experiência segundo os principais autores que se dedicaram ao entendimento desse campo. O tema faz parte das prioridades de pesquisa do Marketing Science Institute Research Priorities, que aponta as prevalências de estudos para a área de marketing. Embora o tema esteja presente na literatura nacional e internacional, os estudos conceituais são encontrados em menor número. Dada a sua importância, esse estudo propõe um entendimento de marketing de experiência, examinado sob uma abordagem conceitual, baseado na apreciação crítica de conceitos relacionados ao marketing de experiência com as dimensões propostas por Schmitt (1999, 2002, 2006, 2010) e na tipologia proposta por Lanier Junior e Rader (2015), considerando que o nível de explicação e intencionalidade de um experimento pode variar para cada consumidor da mesma experiência. O marketing de experiência surge como a nova onda do marketing contemporâneo, proporcionando fidelização e relacionamento, foco dos dias atuais nesta área de estudos.

Palavras-chave: Marketing de experiência. Marketing experiencial. Definição de marketing de experiência.

\section{Marketing de Experiencia: un estudio de los aspectos conceptuales}

\section{Resumen}

El presente estudio tuvo como objetivo central revisar la evolución y los conceptos actuales de marketing de experiencia según los principales autores que se dedicaron al estudio de ese campo. El tema forma parte de las prioridades de investigación del Marketing Science Institute Research Priorities, que apunta las prevalencias de estudios para el área de marketing. Aunque el tema está presente en la literatura nacional e internacional, los estudios conceptuales se encuentran en menor número. Dada su importancia, este estudio propone una comprensión del marketing de experiencia, examinada bajo un enfoque conceptual, basado en una apreciación crítica de los conceptos relacionados con el marketing de experiencia, usando las dimensiones propuestas por Schmitt (1999, 2002, 2006, 2010) y la tipología propuesta por Lanier Junior y Rader (2015), considerando que el nivel de explicación e intencionalidad de un experimento puede variar para cada consumidor de la misma experiencia. El marketing de experiencia surge como la nueva ola del marketing contemporáneo, y el que más proporciona fidelización y relación, foco de los días actuales en esta área de estudios.

Palabras clave: Marketing de experiencia. Marketing experiencial. Definición de marketing de experiencia. 


\section{INTRODUCTION}

The interest in investigating the field of experience marketing arises from it being one of the current subjects of study in the area of marketing. The Marketing Science Institute Research Priorities (MSI, 2017), which points out the prevalence of studies in this area, presents as one of the priorities of marketing research the theme "how to deliver integrated and relevant experiences", assertion to which the marketing of experience is dedicated, in the period from 2016 to 2018.

The experiential view was incorporated into marketing in the 1980s, in order to advance the knowledge of consumer buying behavior, at a time when the emotional element was taken into account as dominant in the buying process (MORAL MORAL and FERNÁNDEZ ALLES, 2012).

Thus, experiential marketing or experience marketing focuses on creating enjoyable experiences not only at the time of purchase, but also at the time of consumption and after-consumption, resorting to the creation of emotions, feelings and thoughts aiming at the interaction between customers and goods or services. In this way, the central nucleus of experiential marketing is experience in the course of consumption (MORAL MORAL and FERNÁNDEZ ALLES, 2012).

The concept of experience marketing was proposed by Schmitt $(1999,2002,2006,2010)$ who "believes that there is a need for a focus that emphasizes the client's experience [...]" (ROESLER and MOLINO, 2016, p. 4). Thus, Marketing Administration shifts from product ("what" is consumed) to experience ("how" it is consumed) and companies start to manage experiences rather than just providing goods and services (LIMA-FILHO, SILVESTRINI, SOUSA et al., 2010).

In this context, the main objective of this article is to review the concept of experience marketing according to the main authors dedicated to the understanding of this field. When discussing the perspective of two of the main authors, we seek to present a complementary proposal to make possible advances in the understanding of the subject from the academic point of view.

The present study is justified for some reasons. Although experience marketing is recognizably important, there is still much to be explored in the field of marketing. The theme is present in the national and international literature, the latter having the predominance of investigations.

In the international literature there are studies on experience marketing for arts (PETKUS JUNIOR, 2004), tourism (HANNAM, 2004), tourism and hospitality (YUAN and WU, 2008), cultural events (ILA-LOPEZ and RODRIGUEZ-MOLINA, 2013) and in sports (STENHOUSE, 2003). There are also studies focused on consumer loyalty and satisfaction (GARCíA BOBADILLA, 2010 apud MORAL MORAL and FERNÁNDEZ ALLES, 2012; LEE et al., 2010; YOU-MING, 2010), and studies focused on introducing the concepts of the subject (BARRIOS, 2012; HOLBROOK, 2000; MORAL MORAL and FERNÁNDEZ ALLES, 2012; PINE II and GILMORE, 1998; SCHMITT, 1999).

Regarding the national literature, most of the research focuses on the retail scenario (AZAMBUJA and BICHUETI, 2016; FARIAS, 2010; FLÔR and UMEDA, 2008; PALMEIRA, SEMPREBOM, FERRARI et al., 2009; ROESLER and MOLIANI, 2016), followed by studies on experience marketing related to brands (ARONNE and VASCONCELOS, 2009; CLARO and DIAS, 2014; COELHO and SANTOS, 2013; FRANCO, MOIA, SILVA et al., 2017; NEVES, BIZARRIAS, SILVA et al., 2017). There are also research related to experience marketing and events (LOBUONO, GOSLING and RODAS VERA, 2016; LOBUONO, GOSLING, GONÇALVES et al., 2016), to the tourism segment (MONDO and COSTA, 2010; PINHEIRO and MELLO, 2015; STEFANINI, ALVES and MARQUES, 2018) and, more recently, studies that relate the subject to sponsorship actions, whether towards sports (YAMAMOTO, CORDOVA and MAZZEI, 2018) or to the development of projects and events (CERQUEIRA, LOPES and SILVA, 2019). Conceptual studies (CABRERIZO and SANTOS, 2011; FARIAS, 2010; PINTO and LARA, 2010; SARGI and MATTOS, 2015) are found in fewer numbers.

The present research recognizes that the vast and complex nature of consumption experiences is a starting point for examining them and encouraging more theoretical investigations, in addition to empirical studies (LANIER JUNIOR and RADER, 2015).

In this sense, the present study proposes an understanding of experience marketing, examined under a conceptual approach, based on the critical appreciation of the concepts related to experience marketing with the dimensions proposed by Schmitt $(1999,2002,2006,2010)$ and the typology proposed by Lanier Junior and Rader (2015), considering that the explicability, the intentionality of an experience may vary in level for each consumer of the same experience. Thus, the theme contributes to broaden the knowledge of this area, since it is an emerging, contemporary and relevant theme. 


\section{EXPERIENCE MARKETING: CONCEPTUAL ASPECTS}

Experience marketing or experiential marketing is a concept in the field of marketing that aims to provide consumers with experiences through the senses and emotions (SARGI and MATTOS, 2015) and has been applied in areas such as retail, branding and marketing of events, and tourism.

The importance of the experiential aspects of consumption was first recognized by Holbrook and Hirschman (1982) who contrasted the rational model of the consumer behavior process with a view of experience, emphasizing the emotional variables - pleasure, dreams, fantasies, feelings and fun - present in consumption and encompassing what they called the vision of experience. From this study, and in continuity with this idea, several researchers worked with the same understanding, that the purchase decision process is not only influenced by rational elements (AHOLA, 2005; HAVLENA and HOLBROOK, 1986 apud PALMEIRA, SEMPREBOM, FERRARI et al., 2009; LINDSTROM, 2005; PINE II and GILMORE, 1998; SHAW and IVENS, 2005; SHAW, 2007).

Similarly, Fontenelle (2017) mentions Holbrook and Hirschman (1982) as those who presented the concept of consumption experience [...] "in contrast to the prevailing paradigm in the field of studies of the consumer, namely, the information processing model" (FONTENELLE, 2017, p. 107).

From that moment on, since experience has been predicted, experience marketing has been a theme that has elicited the interest of academics and marketers in understanding the role of the customer experience (BARRIOS, 2012; TYNAN and MCKECHNIE, 2010).

The studies started in the 1980s, but only in the late 1990s that researchers give more attention to it as an essential element for understanding the consumer purchase behavior.

The theoretical framework of experience marketing concept is the study conducted by Schmitt in 1999, called Experiential Marketing, focusing on the emotion produced by the enjoyment of an experience, when an individual acquires a product or service or a combination of both (MORAL MORAL and FERNÁNDEZ ALLES, 2012). After this study, the ideas of Schmitt (2002, 2003, 2006, 2010, 2013) are still valid and present in other studies.

Additionally, Farias (2010, p. 7) refers to Schmitt (1999) who defined experiential marketing as the "[...] recognition and acquisition of goods or services of a company or brand after having experienced activities and perceived stimuli". Experiential marketing encourages customers to make faster and more positive purchase decisions (FARIAS, 2010).

As for Palmeira, Semprebom, Ferrari et al. (2009, p. 3), emotion plays a fundamental role in experiential marketing, which "[...] focuses on the experiences of clients and this individual becomes emotionally involved with the object of the experience, something that can be a product or a service".

Also, for Roesler and Moliani (2016, p. 3), emotion is the central focus, defined as "[...] a term used to refer to a new marketing method, whose objective is to emotionally affect the consumer through induced experiences. Experiential marketing is not focused on the purchase itself; it focuses on the emotion".

Franco, Moia, Silva et al. (2017) refer to Schmitt's argument (2002) that in experiential marketing, "the use of experiences [...] should be part of marketing strategies, mainly involving neurobiological and psychological factors". Consumer behavior is understood from psychological theory and practice so that companies can develop their communication and marketing strategies with experiential focus (FRANCO, MOIA, SILVA et al., 2017, p. 156).

Stefanini, Alves and Marques (2018, p. 64) take as their definition basis the studies developed by Schmitt (1999) and argue that "experience marketing involves several aspects and is not limited to a single dimension [...]", referring to the five dimensions already mentioned by Schmitt (1999).

Yamamoto, Cordova and Mazzei (2018) mentioned Schmitt (1999) who also consider emotional attributes as a central point. "The main characteristic of Experience Marketing is to provide experiences in which individuals are encouraged to have some type of emotional stimulation and, thus, convince them to purchase or lead to a good Brand Equity of the product/company that organizes or promotes a particular experience" (YAMAMOTO, CORDOVA and MAZZEI, 2018, p. 66). 
Lastly, Cerqueira, Lopes and Silva (2019, p. 26) are also based on the ideas Schmitt (2010) had already mentioned, which are "[...] the perceptions, feelings and thoughts that consumers have when they find the products and brands and engage in consumption activities - as well as the memory of such experiences". They emphasize the memory that the consumer keeps of their experiences (CERQUEIRA, LOPES and SILVA, 2019).

Box 1 presents the concepts of experience marketing, according to the main authors dedicated to understanding this field.

\section{Box 1}

Definition of experience marketing

\begin{tabular}{|c|c|}
\hline Author & Concept \\
\hline Schmitt (1999, p. 57) & $\begin{array}{l}\text { Focuses on customers experiences. The experiences occur as a result of an } \\
\text { encounter, going through something or experiencing things. Experiences provide } \\
\text { sensorial, emotional, cognitive, behavioral and relational values that replace } \\
\text { functional values. }\end{array}$ \\
\hline Schmitt $(2002,2006)$ & $\begin{array}{l}\text { It is a marketing approach whose objective it to create different types of } \\
\text { experiences for customers. The focus of experience marketing is the consumer } \\
\text { experience, which results from the encounter and experience of situations, where } \\
\text { stimuli are created for the senses, feelings and mind, replacing the functional } \\
\text { values. }\end{array}$ \\
\hline $\begin{array}{l}\text { Palmeira, Semprebom, } \\
\text { Ferrari et al. (2009) }\end{array}$ & $\begin{array}{l}\text { Focuses on the experiences of the clients and this individual becomes emotionally } \\
\text { involved with the object of the experience. }\end{array}$ \\
\hline Schmitt (2010, p. 63) & $\begin{array}{l}\text { "Any form of customer-focused marketing activity that creates a connection with } \\
\text { customers. Based on this broad vision, experiences can be stimulated in products, } \\
\text { packaging, communications, in-store interactions, sales relationships, events, and } \\
\text { so on. They can occur as a result of online or offline activities". }\end{array}$ \\
\hline Farias $(2010$, p. 7$)$ & $\begin{array}{l}\text { "Acquisition of goods or services after the consumer has experienced activities } \\
\text { and perceived stimuli". }\end{array}$ \\
\hline $\begin{array}{l}\text { Schmitt and Zarantonello } \\
\text { (2013) }\end{array}$ & $\begin{array}{l}\text { Value is also in the hedonic and experiential system, and in the consumption } \\
\text { experience. }\end{array}$ \\
\hline Sargi and Mattos (2015) & Provide consumers with experiences through the senses and emotions. \\
\hline Roesler and Moliani (2016) & $\begin{array}{l}\text { A new marketing method, whose objective is to emotionally affect the consumer } \\
\text { through induced experiences. }\end{array}$ \\
\hline $\begin{array}{l}\text { Franco, Moia, Silva et al. } \\
\text { (2017, p. 156) }\end{array}$ & $\begin{array}{l}\text { "The use of experiences [...] should be part of marketing strategies, involving } \\
\text { mainly neurobiological and psychological factors." }\end{array}$ \\
\hline $\begin{array}{l}\text { Stefanini, Alves and Marques } \\
(2018, \text { p. 64) }\end{array}$ & $\begin{array}{l}\text { "Experience marketing involves many aspects and is not limited to a single } \\
\text { dimension }[\ldots] \text { ". }\end{array}$ \\
\hline $\begin{array}{l}\text { Yamamoto, Cordova and } \\
\text { Mazzei, }(2018, \text { p. 66) }\end{array}$ & $\begin{array}{l}\text { "Provide experiences in which individuals are encouraged to have some kind of } \\
\text { emotional stimulation". }\end{array}$ \\
\hline $\begin{array}{l}\text { Cerqueira, Lopes and Silva } \\
(2019, \text { p. } 26)\end{array}$ & $\begin{array}{l}\text { "The perceptions, feelings and thoughts consumers have when they find products } \\
\text { and brands and engage in consumption activities- as well as the memory of such } \\
\text { experiences". }\end{array}$ \\
\hline
\end{tabular}

Source: Elaborated by the authors.

According to Smith and Hanover (2016), the first steps towards Experiential Marketing go back to promotional marketing, since a survey (mentioned by them) in the mid-1980s pointed out that $2 / 3$ of the purchase decisions were made inside the store. For those authors, it would benefit those companies that "combined brand message with an incentive that would lead the consumer to the purchase action and the creation of a compelling story with the effort to create an emotion" (SMITH and HANOVER, 2016, p. 5).

One of the main objectives of the experiential marketing is to create buzz and conversations about a product, since live experiences are considered one of the drivers of word-of-mouth communication. Talking positively about a product, service or brand can 
offer a distinct competitive advantage, and is much more effective in converting unfavorable or neutral predispositions into positive attitudes when compared to traditional advertisements. This is because the communicator is not seen as selling the product, but rather sharing the information expressively. In addition, word-of-mouth is more vivid, making it more accessible in memory and with more weight in cognitive judgments (ARONNE and VASCONCELOS, 2009).

According to Smith and Hanover (2016), marketers began to realize that companies directed their marketing budgets toward actions that could be closer to their consumers in order to increase their sales. This happened around the time Pine and Gilmore (1998) released their book stating that the growth of the economy depended on the value of the experience. Marketing actions geared to the events of the brand were intensified in order to create memorable experiences to the consumers.

According to Smith and Hanover (2016), marketing actions such as advertising, promotional marketing, direct marketing or digital marketing have limited scope. The contemporary consumer interacts in real time with the brands of his interest, giving less importance to the opinions of the sellers and more to the opinion of other consumers on social networks, searching for information, interacting with other consumers, and providing new information according to their own experiences. The authors argue that nowadays, experience marketing has become "the new traditional marketing" (SMITH and HANOVER, 2016, p. 12).

\title{
Key Characteristics of Experience Marketing
}

Palmeira and collaborators $(2009$, p. 3 ) highlight four fundamental characteristics of experiential marketing: a) it is focused on clients experiences; b) seeks to understand the meaning of the consumption situation, treating it as a holistic experience; c) is aware that clients "want to be entertained, stimulated, emotionally affected and creatively challenged" (Schmitt 1999, p. 29); d) is eclectic, using different methodologies, seeking interactivity.

As for Schmitt (2006 apud MORAL MORAL and FERNÁNDEZ ALLES, 2012) the key characteristics of experience marketing are presented in Box 2:

\section{Box 2}

Key characteristics of experience marketing

\begin{abstract}
The main peculiarity is the customer experience, which is the result of a stimulus raised by the mind or the senses, in situations that make it possible to connect the brand or company to the customer. The experiences bring cognitive, emotional and sensorial values substituting the functional values of the product.

Individuals are considered rational and emotional subjects and, because of this, they base their decisions on rational and emotional elements. In this sense, experiential marketing considers that the individual wants to receive stimuli and experiences full of creativity and emotion.

The customer evaluates the consumption experiences experienced during the consumption situation, not just the functional characteristics and benefits of the product. The examination of the consumption situation is then considered within a broader context, called socio-cultural vector of consumption, amplifying beyond the category of the product.
\end{abstract}

Source: Adapted from Moral Moral and Fernández Alles (2012).

\section{The Five Dimensions of Experience Marketing}

Schmitt $(1999,2002,2006,2010)$ outlined the five types of consumer experience, presenting them as the five approaches to experience marketing. According to the author, consumers can experience an experience through: a) the senses (sight, hearing, touch, taste and smell); b) the feelings, through emotions or a positive state of humor that bind consumers favorably to brands; c) the thought, the cognition which are the resources of the intellect involving the customers in a creative way; d) the action, which aims at physical, corporal experiences or activities that show interest in a certain lifestyle; and, lastly, e) relating, where experiences are created taking into account the desire of the individual to be part of a social context. 


\section{a) Sensorial dimension}

The sensorial element involves the five senses and affects our perceptions, judgment and behavior. It can be used to evaluate the perception of abstract attributes such as color, taste, texture, smell (BARRIOS, 2012). Using these factors can cause unwanted effects, such as too many colors can distract the customer; well-known background music can cause the customer to buy fewer items and spend less in the store because they pay attention to the music. Therefore, misuse of these factors may disturb the consumer's buying decision. The sensorial marketing approach fills the gaps of the overly rational, traditional marketing (DAUCÉ and RIEUNIER, 2002).

When the potential of the individual's five senses is explored, the goal is to target the consumer subconscious. Emotions generate the memory of that sensation and this goes beyond simply words or images, because it deals with the immediate responses of the sensorial organs, closely linked to the brain. Thus, a thought is created, giving rise to a judgment. This sensorial approach is linked to the individual's perception zones that produce a stimulus, not necessarily a decision. However, a stimulus allows the consumer to make the decision (BATEY, 2010).

Given the relevance of the five senses, each is examined below:

- Sight

In marketing, the sight is one of the most used and most stimulated senses. The selection of colors, product design, the visual of the campaigns, the packaging of the products or the point of sale are factors of success or failure for the companies, since through this sense consumers can memorize brands more easily. In addition to color, shape and size are also explored once they are being quickly perceived, and in some cases, directly influencing our emotions. The use of text is also another important visual element that deserves to be highlighted because, through it, the consumer may feel attracted or not by the product (BARRIOS, 2012). And regarding the environment, light is also an essential component, acting on our perception according to its intensity (whether strong or weak, it generates distinct behavioral responses from buyers), whether the source is natural or artificial, increasing or not the sense of well-being or time spent in the environment. It also allows guiding the search for information and influences the amount of products purchased, i.e., customers buy more when they like the light of the environment (DAUCÉ and RIEUNIER, 2002).

- Hearing

The vast majority of marketing communications are of auditory nature. We often hear messages on the radio, on TV, their jingles and songs, music at the point of sale, at restaurants, and even on airplanes. The sound of the word induces the perception of the object it represents, increasing the associations that a brand can have (KRISHNA, 2012). The investigations highlight the impact of music on consumer behavior in retail. Currently, it is present in most points of sale as an integral part of the atmosphere of the stores, as video clips, TV or ambient music. Even in the case of food trucks, many events feature local bands or DJs, bringing together gastronomy and music. Music has the power to contextualize different products (GUMPERZ, 1977; DENORA, 1986 apud BARRIOS, 2012), placing customers in a state consistent with the products or services that the company sells. For example, playing a rock song at a store that sells guitars. Therefore, it is a way of connecting with the product, acting on the customer purchase behavior (BARRIOS, 2012).

- Smell

The perception of smell differs from person to person and companies should take this into count. Women are more sensitive to smell than men, and each gender has distinct reactions to smell (HIRSCH and GAY, 1991 apud BARRIOS, 2012). Studies show that people can recognize smell with minimal levels of memory even after months or years of exposure. The scent in the environment enhances the memory and recognition of brands. When there is a pleasant scent in the environment during brand exposure, consumers spend more time on site and pay more attention to the brand. Because of this they create a deeper memory regardless of the scent being present again during brand recovery (MORRIN and RATNESHWAR, 2003), and a pleasant smell tends to intervene positively in the client evaluation of the time spent in the store.

Also, the olfactive memory is responsible for evoking pleasant or unpleasant memories; that will interfere directly in the purchasing process and the loyalty to the brands.

Scent can lead to an enhanced subjective experience for retail shoppers, influencing the time consumers spend scanning merchandise, waiting in lines, or waiting for help. This waiting time may seem shorter than it actually is by introducing scent into the environment (SPANGENBERG, CROWLEY and HENDERSON, 1996). 


\section{- Taste (Palate)}

Humans are able to distinguish five flavors: sweetness, saltiness, bitterness, sourness and umami (Japanese word meaning "savory") and are combined with our other senses: smell (aroma of food), touch (temperature, texture of foods), sight (as seen including color of food), hearing (the sound of a caramel when we bite it). Many factors act on the perception of taste such as the ingredients used or even the nutritional information of the products (BARRIOS, 2012). The palate is the sense addressed by products in the food sector. It is chemically linked to the smell, one completing the other. Smell awakens the palate which without the scent practically does not work. Elderly people have this sense less accurate, because aging tend to diminish the gustative receptors capacity. Children have this sense very strong (OLIVEIRA and BRAGA, 2013). Therefore, we can find different emotions according to the age range for this sense.

- Touch

Touch is one of the main determinants of well-being. The softness of a napkin, the weight or shape of the cutlery or even the comfort of a chair can affect customers perception of the company or of the location (BARRIOS, 2012). It also affects how consumers react to the products, provoking attraction or aversion, for example, products on supermarket shelves can be deemed as gross or attractive, when research has shown that putting female tampons near potato chips reduces the appeal of the potato. Also, consumers are less likely to buy certain products if another buyer has touched it before (KRISHNA, 2012).

\section{b) Feeling dimension}

It consists of employing emotional stimuli to sensitize the mood and emotion of the consumer, which can range from positive mood to strong emotions of joy and pride. Usually the most vivid impressions occur during consumption, but also from contact with the product over time. The greater the number of positive experiences repeated with the product or service, the more incisive and positive the emotion that will be developed (SCHMITT, 2002). Personal feelings and emotions of the consumer generate certain affective and emotional experiences - fear, optimism, discontent, shame, love, joy, worry, envy, tranquility, enthusiasm, sadness, contentment, loneliness - and it is important that the experience provider know the acceptance or empathy of the consumers with regard to the stimuli created (SCHMITT, 2002). The personal interaction in situations of consumption is what causes more feelings, because of human contact. And such feelings or emotions can be positive or negative.

\section{c) Cognitive dimension}

The purpose here is to encourage the consumer to think, engaging him in elaborate and creative thinking that can even result in paradigm shifts, making people think differently about existing expectations (SCHMITT, 2002).

\section{d) Action dimension}

"The intention is to create experiences related to the body that modify behavior patterns, lifestyles or interaction with other people" (SCHMITT, 2002, p. 163). Our body is rich in experiences and is a fertile source of sensations and perceptions. For example, a manicure or massage service creates stimuli that are related to experiencing sensations in our body. The experience affects not only the physical body, but through the body we can reach some mental states. Certain motor actions or body movements can change the state of our mind. An individual who practices Tai Chi makes movements that result in quieter mental states. Also, through the body we can perform some motor actions that denote non-verbal behavior in social interactions, which can influence people's attitudes. For example, some gestures may suggest approximation, withdrawal or preference. A salesperson may be standing with a gesture that denotes disinterest and may discourage the consumer approach, while another may be solicitous through a smile or a facial expression that demonstrates sympathy (SCHMITT, 2002).

\section{e) Relational dimension}

This dimension addresses the experiences concerning the interaction between people, relating it to the social context. The aim is to achieve a connection with other people or other social groups. Non-virtual buying situations are conducive to this, and the more people identify with each other, the greater the significance of that relationship. Identification can also occur with a social group, which leads to a sense of belonging to a group, also distinguishing between other groups. 


\section{Structural and functional aspects of the consumption experience}

Caru and Cova (2013) propose an analysis of the consumption experience based on different intensities between two axes. According to the authors, the first is defined as an opposition between ordinary and extraordinary events for the consumer. The second indicates a polarization between the forces exerted by the consumer, in opposition to the ones originated from society.

Using a two-dimensional perspective, Lanier Junior and Rader (2015) discuss a structure of analysis of consumption experiences that explicitly details the relationship between structural and functional aspects.

Based on the two broad dimensions (structure and function) and their respective subdimensions, Lanier Junior and Rader (2015) propose a "2x2" matrix that classifies four main types of consumption experiences: (a) performance experiences (structure / function), (b) liberating experiences (anti-structure / function), (c) stochastic experiences (structure / anti-function), and (d) adventure experiences (anti-structure / anti-function) (LANIER JUNIOR and RADER, 2015, p. 8).

\section{a) Performance experiences}

Often interpreted as common experiences, as what distinguishes these experiences is the acceptance of the structures of the society, which are often associated with the commercial, worldly and profane. In fact, performance experiences can be considered as a celebration of the structural factors of our society.

\section{b) Liberating experiences}

Liberating experiences are conceptualized as consumption experiences that directly address the anti-structural relationships (i.e., unstable, inconsistent, and disordered) that ground a cultural form and produce and promote functional consequences (i.e., apparent, explicable and intentional).

c) Stochastic experiences

Stochastic experiences are conceptualized as consumer experiences that directly address the structural (i.e., stable, consistent, and dominant) that underlie a cultural form, but which manifest anti-functional consequences (i.e., ambiguous, unexplained, and unintentional) that actually reinforce and support these structural relationships.

d) Adventure experiences

In this typology, adventure is not simply an aspect of an experience; it is a specific type of experience distinguished by its ability to resist any attempt to include it in a structural form or functional consequence. For example, Simmel (1997) argues that adventure has four distinct characteristics: (i) is apart from everyday life, (ii) $t$ activates the indefinite, uncertain and indeterminate aspects of existence, (iii) transforms the person into a history, and (iv) is a process, not content.

However, for better understanding these concepts, it was necessary to exemplify and base them on research. Box 3 , points out and clarifies these aspects:

\section{Box 3}

Classification of consumption experiences

\begin{tabular}{|l|l|l|l|}
\hline \multicolumn{1}{|c|}{$\begin{array}{c}\text { Types Of } \\
\text { Experiences }\end{array}$} & \multicolumn{1}{|c|}{$\begin{array}{c}\text { structural } \\
\text { relations }\end{array}$} & \multicolumn{1}{c|}{$\begin{array}{c}\text { Functional } \\
\text { Consequences }\end{array}$} & \multicolumn{1}{c|}{ Research Areas } \\
\hline $\begin{array}{l}\text { Performance } \\
\text { Experiences }\end{array}$ & Structure & Functional & $\begin{array}{l}\text { Branded stores (SHERRY JUNIOR, 1998), retail } \\
\text { environments (MACLARAN and BROWN, 2005), sporting } \\
\text { events (HOLT, 1995), television programs (FITCHETT, 2004), } \\
\text { video games (DENEGRI-KNOTT and MOLESWORTH, 2010) } \\
\text { and fairs (PEÑALOZA, 2001). }\end{array}$ \\
\hline $\begin{array}{l}\text { Liberating } \\
\text { Experiences }\end{array}$ & Anti-structure & Functional & $\begin{array}{l}\text { Magic, fantasy, games and creativity (ARNOULD and PRICE, } \\
\text { 1993; BELK and COSTA, 1998; KOZINETS, 2001). }\end{array}$ \\
\hline $\begin{array}{l}\text { Stochastic } \\
\text { Experiences }\end{array}$ & Structure & Anti-functional & $\begin{array}{l}\text { Gamble (COSGRAVE, 2006; COTTE and LATOUR, 2009; } \\
\text { HUMPHREYS, 2010). }\end{array}$ \\
\hline $\begin{array}{l}\text { Adventure } \\
\text { Experiences }\end{array}$ & Anti-structure & Anti-functional & $\begin{array}{l}\text { Tourism, trips and leisure (EWERT, 1989; PRIEST, 1992; } \\
\text { WEBER, 2001). }\end{array}$ \\
\hline
\end{tabular}

Source: Adapted from Lanier Junior and Rader (2015). 


\section{Discussion of data}

Although the dimensions proposed by Schmitt $(1999,2002,2006,2010)$ are widely discussed, there is a conceptual problem in bringing the five dimensions together. The sensorial dimension is equated with the others, since the stimuli generated by this dimension are created by the marketing and received and interpreted by the consumers. The author puts stimulus and reaction at the same level, calling Dimension the steps that bring a causal relationship.

According to the interpretation itself, the consumer can go through the experience giving some meanings (or responses) to the experiences. These responses are the other four dimensions proposed by Schmitt $(1999,2002,2006,2010)$. Thus, the author considers stimuli and responses to stimuli as if they stem from the marketing decision, which does not occur, since the responses resulting from the sensorial stimuli (sight, smell, touch, taste and hearing) may be a combination of the other dimensions (emotion, cognition, behavior or social relationship).

The typology proposed by Lanier Junior and Rader (2015) is an advance due to the possibility of framing the types of experience based on the dimensions of structure and function, which are preponderant for the decision of the consumer. However, using the dichotomous structure of Turner (1969) for structure and anti-structure, this typology forces the framing of the types of structure in a categorical and static way.

This fragility is replicated using the logic of Merton (1957) dichotomically, which may generate questions for the areas used by the research on experience. The function refers to the consequences that are apparent, explicable and generally intended, and anti-function refers to ambiguous, inexplicable and often unintended consequences.

This dichotomy hinders the framing of experiences that may be apparent, but not intentional, for example, since the process of rationality may indicate a gradual path of analysis. Thus, the explicability, the intentionality of an experiment can vary in level for each consumer of the same experience, reinforcing the importance of adopting a broader understanding of the meaning of the consumer situation.

Just as we identified in Schmitt's dimensions (SCHMITT, 1999, 2002, 2006, 2010) the need for separation between what is defined by the market and what is defined by the consumer, we can draw a parallel between the structural relationships and the functional consequences used by Lanier Junior and Rader (2015). The detailing of functionality, as a consequence of the marketing decision, if analyzed gradually and non-categorically (functional and anti-functional), can help to understand the typology of the experiences and allows a better clarification regarding the decisions made by companies and intended results from the consumer experience.

Understanding the process that begins with marketing experience, based on market decision making regarding sensory stimuli (SCHMITT, 1999, 2002, 2006, 2010) and structure (LANIER JUNIOR and RADER, 2015) and which can provide results by consumers, according to functionality (LANIER JUNIOR and RADER, 2015) and the expected responses, whether of emotion, cognition, behaviors and interactions (SCHMITT, 1999, 2002, 2006, 2010), can bring contributions to various market segments that have experience as their main attribute.

\section{FINAL CONSIDERATIONS}

Over the last few decades, the concept of experience marketing has been transformed, as a result of social interactions. In this article, we sought to study the conceptual aspects of experience marketing, exploring the definitions according to the main authors dedicated to understanding the field, as well as presenting the key elements and the five dimensions of the experience proposed by Schmitt (1999, 2002, 2006, 2010): sensorial, feeling, cognitive, action and relational dimension. It is one of the current topics pointed out as a priority of marketing research and considered important for the understanding of the field of consumer behavior.

Based on the critical appraisal of the concepts related to the Experience Marketing, the difference in relation to the consumption marketing is verified, not being a mere evolution of the latter. Experience refers to an attempt to explore the senses employed in the individual's apprehension of reality. In a contemporary context, the discussion is embodied by the interpolation of sensorial factors, with predominance of the audiovisual, amid the escalation of exploration of the image and the movement by parts of the communication vehicles. In addition, the search for more comprehensive forms of interaction with the public 
is necessary in scenarios with a tendency to disruption, in economies more into the cognitive dimension and little related to the analysis of linear studies.

Conceptualizing and establishing limits of applicability to experience marketing is valuable in establishing limits and applications, minimizing false expectations and intuitive practices, especially for the activities in the service and commerce sectors, which tend to generate gaps in the interlocution between what is promised and what is delivered to the consumer. Through the study of the complex pathways to be developed by the organizations in the relationship with the public, the experience is a sum of synesthetic factors that involve the public, the organizations and the context in which they are inserted.

The development of frameworks and models that take into consideration the decisions made by the companies and that are related to aspects that are intrinsic to the consumer, but affect how experiences are perceived and evaluated, can broaden the relevance of experiential marketing with greater involvement in customer experiences. 


\section{REFERENCES}

AHOLA, E. How is the concept of experience defined in consumer culture theory? Discussing different frames of analyses. Kuluttajatutkimus Nyt, v.1, p. 91-98, Jan. 2005.

ARNOULD, E. J.; PRICE, L. L. River Magic: Extraordinary Experience and the Extended Service Encounter, Journal of Consumer Research, v.20, n.1, p. 24-45, June 1993.

ARONNE, C.; VASCONCELOS, M. C. The Impact of Experiential Marketing on the Customer's Perception of a Brand's Essence. In: ENCONTRO DA ANPAD, 33., 2009, São Paulo. Anais... São Paulo: ENANPAD, 2009.

AZAMBUJA, C; BICHUETI, R. Marketing de Experiência: Estratégias para Impulsionar o Market Share e Fortalecer a Marca do Energético Energy. Revista de Administração da UFSM, Santa Maria, v. 9, ed. esp., p. 88-106, Aug. 2016.

BARRIOS, M. Marketing de la Experiencia: principales conceptos y características. Palermo Business Review, Buenos Aires, n. 7, p. 67-89, Dec. 2012.

BATEY, M. O significado da marca: como as marcas ganham vida na mente dos consumidores. Rio de Janeiro: Best Business, 2010.

BELK, R. W.; COSTA, J. A. The Mountain Man Myth: A Contemporary Consuming Fantasy, Journal of Consumer Research, v. 25, n. 3, p. 218-40, Dec.1998.

CABRERIZO, A.; SANTOS, L. Marketing Experiencial e Consumo: Eventos de marketing como ferramenta prioritária do marketing experiencial. In: CONGRESSO BRASILEIRO DE CIENCIAS DA COMUNICAÇÃO, 16., São Paulo. Anais... São Paulo: Intercom, 2011.

CARÙ, A; COVA, B. Revisiting consumption experience: a more humble but complete view of the concept. Marketing theory, v. 3, n.2, p. 267-286, June, 2003.

CERQUEIRA, A.; LOPES, E.; SILVA, J. No Backstage do Marketing da Experiência: A Ótica dos Gestores na Aplicação de Estratégias de Branding por Meio de Ações de Patrocínio e Desenvolvimento de Projetos e Eventos. Future Studies Research Journal, v. 11, n. 1, p. 25-47, Jan./Apr. 2019.

CLARO, J.; DIAS, A. Estratégia da Razão à Emoção: Experience Marketing e a Marca Líder. Journal of Economic Sociology Studies, v. 4, n. 1, p. 312-325, Jan./Apr. 2014.

COELHO, M.; SANTOS, P. F. de A. A. dos. Marketing de experiência do smartphone: a cocriação de valor por meio dos aplicativos de celular. Revista Brasileira de Pesquisas de Marketing, Opinião e Mídia, São Paulo, v. 13, p.46-66, Oct. 2013.

COSGRAVE, J. F. (Ed). The Sociology of Risk and Gambling. New York: Routledge, 2006.

COTTE, J.; LATOUR, K. A. Blackjack in the Kitchen: Understanding Online versus Casino Gambling. Journal of Consumer Research, v. 35, n. 5, p. 742-558, Sept. 2009.

DENEGRI-KNOTT, J.; MOLESWORTH, M. Concepts and Practices of Digital Virtual Consumption. Consumption, Markets and Culture, v. 13, n. 2, p. 109-132, June 2010.

EWERT, A. Outdoor Adventure Pursuits: Foundations, Models and Theories. Columbus, OH: Publishing Horizons, 1989.
FARIAS, S. Store Atmospherics and Experiential Marketing: a conceptual framework and research propositions for an extraordinary customer experience. In: ENCONTRO DE MARKETING DA ANPAD, 4., Florianópolis, 2010. Anais... Florianopólis: ANPAD, 2010.

FITCHETT, J. A. The Fantasies, Orders, and Roles of Sadistic Consumption: Game Shows and the Service Encounter. Consumption, Markets and Culture, v. 7, n. 4, p. 285-306, Dec. 2004.

FRANCO, N. et al. A Importância do Marketing de Experiência no Fluxo Logístico de um Parque Temático. Estudo de Caso: Walt Disney. South American Development Journal Society, v. 5, n. 2., p. 149161, July 2017.

FLÔR, P.; UMEDA, G. O Marketing Olfativo como Aplicação do Marketing Experimental: Uso de Aromatizantes no Varejo. In: CONGRESSO BRASILEIRO DE CIENCIAS DA COMUNICAÇÃO, 13., São Paulo, 2008. Anais...São Paulo: Intercom, 2008.

FONTENELLE, I. Cultura do Consumo: fundamentos e formas contemporâneas. Rio de Janeiro: Editora FGV, 2017.

HANNAM, K. Tourism and development II: marketing destinations, experiences and Crises. Progress in Development Studies, v. 4, n. 3, p. 256-263, July 2004.

HOLBROOK, M.; HIRSCHMAN, E. The Experiential Aspects of Consumption: Consumer Fantasies, Feelings, and Fun. Journal of Consumer Research, v. 9, p. 132-140, 1982.

HOLBROOK, M. The Millennial Consumer in the Texts of Our Times: Experience and Entertainment. Journal of Macromarketing, v. 20, n. 2, p.178-192, Dec. 2000.

HOLT, D. B. How Consumers Consume: A Typology of Consumption Practices, Journal of Consumer Research, v. 22, n.1, p. 1-16, June 1995.

HUMPHREYS, A. Semiotic Structure and the Legitimation of Consumption Practices: The Case of Casino Gambling, Journal of Consumer Research, v. 37, n.3, p. 490-510, Mar. 2010.

ILA-LOPEZ, N.; RODRIGUEZ-MOLINA, M. C. Event-brand transfer in an entertainment service: experiential marketing. Industrial Management \& Data Systems, v. 113, n. 5, p. 712-731, 2013.

KOZINETS, R. V. Utopian Enterprise: Articulating the Meanings of Star Trek's Culture of Consumption, Journal of Consumer Research, v. 28, n. 1, p. 67-88, June 2001.

KRISHNA, A. An integrative review of sensory marketing: Engaging the senses to affect perception, judgment and behavior. Journal of Consumer Psychology, v. 22, n. 3, p. 332-351, July 2012.

LANIER JUNIOR, C. D.; RADER, C. S. Consumption Experience: an Expanded View, Marketing Theory, v. 15, n.4, p. 487-508, Dec. 2015.

LEE, M.; HSIAO, H.; YANG, M. The Study of the Relationship among Experiential Marketing, Service Quality, Customer Satisfaction and Customer Loyalty. International Journal of Organization Innovation, v.3, n.2, p. 352-378, 2010.

LIMA-FILHO, D. et al. Experiência de consumo em restaurantes comerciais. FACEF Pesquisa, Franca, v. 13, n. 1, p. 80-92, 2010. 
LINDSTROM, M. Brand Sense: How to build powerful brands through touch, taste, smell, sight \& sound. London: Kogan Page Limited, 2005.

LOBUONO, R. et al. Relações entre Dimensões da Experiência, Satisfação, Recomendação e Intenção de Retornar: A Percepção de Participantes de Evento Cultural. PODIUM Sport, Leisure and Tourism Review v. 5, n. 2 May/Aug. 2016.

LOBUONO, R.; GOSLING, M.; RODAS VERA, L. Experiência Em Eventos Culturais: Um Estudo Sobre a Virada Cultural De Belo Horizonte 2014. Turydes Revista Turismo y Desarrollo, n. 20, June. 2016. Available at: <http://www.eumed.net/rev/turydes/20/eventos-culturais.html>. Accessed on: July 16, 2017.

MACLARAN, P.; BROWN, S. The Center Cannot Hold: Consuming the Utopian Marketplace, Journal of Consumer Research, v. 32, n. 2, p. 311-323, 2005.

MERTON, R. K. Social Theory and Social Structure. Glencoe, IL: The Free Press, 1957.

MORAL MORAL, M.; FERNÁNDEZ ALLES, M. T. Nuevas Tendencias del Marketing: El Marketing Experiencial. ENTELEQUIA Revista Interdisciplinar, n. 14, p. 237-251, May 2012.

NEVES, F. et al. A influência da relação afetiva e experiencial no processo de criação de lealdade: uma análise do mercado de telefonia móvel no Brasil. Revista Ciências Administrativas, Fortaleza, v. 23, n. 1, p. 156-185, Jan./Apr. 2017.

OLIVEIRA, R.; BRAGA, N. Os Cinco Sentidos no Marketing: A Importância dos Estímulos Multissensoriais para Despertar a Emoção e Gerar Inclusão Social. In: CONGRESSO DE CIÊNCIAS DA COMUNICAÇÃO NA REGIÃO SUDESTE, 18., 2013, Bauru, SP,. Anais... Bauru: Intercom, 2013. p. $1-15$

PALMEIRA, M. et al. Experiential Marketing in Bookstores an Analyses of Business Strategy and Customer Experience. In: ENCONTRO DA ANPAD, 33., 2009. São Paulo. Anais... São Paulo: ANPAD, 2009.

PEÑALOZA, L. Consuming the American West: Animating Cultural Meaning at a Stock Show and Rodeo, Journal of Consumer Research, v. 28, n. 3, p. 369-398, Dec. 2001.

PETKUS JUNIOR, E. Enhancing the application of experiential marketing in the arts, International Journal of Nonprofit and Voluntary Sector Marketing, v. 9 n. 1, p. 49-56, Feb. 2004.

PINE II, B. J.; GILMORE, J. H. The Experience Economy: work is theatre and every business a stage. Boston: Editorial Harvard Business School Press, 1998.

PINTO, M.; LARA, J. As Experiências de Consumo na Perspectiva da Teoria da Cultura do Consumo: identificando possíveis interlocuções e propondo uma agenda de pesquisa. Cadernos EBAPE.BR, Rio de Janeiro, v. 9, n. 1, p. 38-56, Mar. 2011.

PRIEST, S. Factor Exploration and Confirmation of the Dimensions of an Adventure Experience, Journal of Leisure Research, v. 24, n. 2, p. 127-139, Apr. 1992.

ROESLER, G.; MOLIANI, J. O uso da loja conceito e do marketing de experiência no setor de bebidas: um estudo de caso do Bar da Brahma.
In: CONGRESSO BRASILEIRO DE CIÊNCIAS DA COMUNICAÇÃO, 39., 2016. São Paulo. Anais... São Paulo: Intercom, 2016.

SARGI, L; MATTOS, A. O marketing de experiência e a sua importância no cenário mercadológico atual. In: CONGRESSO DE CIÊNCIAS DA COMUNICAÇÃO NA REGIÃO CENTRO-OESTE, 17., 2015, Campo Grande, MS. Anais... Campo Grande: Intercom, 2015. p. 1-10.

SCHMITT, B. Experiential Marketing. Barcelona: Deusto, 2006.

SCHMITT, B. Experiential Marketing. Journal of Marketing Management, v. 15, p. 53-67, Feb. 1999.

SCHMITT, B. Experience Marketing: Concepts, Frameworks and Consumer Insights. Foundations and TrendsR in Marketing, v. 5 n. 2, p. 55-112, 2010.

SCHMITT, B. Marketing Experimental. São Paulo: Nobel, 2002.

SCHMITT, B.; ZARANTONELLO, L. Consumer Experience and Experiential Marketing: a critical review. Review of Marketing Research, v. 10, p. 25-61, 2013.

SHAW, C.; IVENS, J. Building Great Customer Experiences. New York: Palgrave MacMillan, 2005.

SHAW, C. The DNA of Customer Experience how emotions drive value. New York: Palgrave MacMillan, 2007.

SHERRY JUNIOR, J. F. The Soul of the Company Store: Nike Town Chicago and the Emplaced Brandscape. In: SHERRY JUNIOR, J. F. (Ed). ServiceScapes: The Concept of Place in Contemporary Markets. Chicago: NTC, 1998. p. 109-146.

SMITH, K; HANOVER, D. Experiential Marketing: Secrets, Strategies, and Success Stories from the World's Greatest Brands. New Jersey: Wiley, 2016

STEFANINI, C. J.; ALVES, C. A.; MARQUES, R. B. Vamos Almoçar? Um Estudo da Relação Hospitalidade, Qualidade em Serviços e Marketing de Experiência na Satisfação dos Clientes de Restaurantes. Revista Brasileira de Pesquisa e Turismo, v. 12, n. 1, p. 57-79, Jan./Apr. 2018.

STENHOUSE, A. Experience marketing in action: the Fox Kids Cup. Advertising and Marketing to Children, v. 4, n. 4, p. 11-16, 2003.

TURNER, V. W. The Ritual Process: Structure and Antistructure. Ithaca: Cornell University Press, 1969.

YAMAMOTO, P.; CORDOVA, M.; MAZZEI, L. Descrição de um Caso Envolvendo Marketing de Experiência através de Patrocínio Esportivo no Segmento B2b. PODIUM Sport, Leisure and Tourism Review, v.7, n. 1, p. 64-78, Jan/Apr. 2018

YUAN, Y. E.; WU, C. K. Relationships Among Experiential Marketing, Experiential Value, and Customer Satisfaction. Journal of Hospitality \& Tourism Research, v. 32, n. 3, p. 387-410, Aug. 2008. Available at: <http://journals.sagepub.com/doi/abs/10.1177/1096348008317392>. Accessed on: July 16, 2017.

WEBER, K. Outdoor Adventure Tourism: a Review of Research Approaches. Annals of Tourism Research, v. 28, n. 2, p. 360-377, Jan. 2001. 
Maria Teresa Grimaldi Larocca

ORCID: https://orcid.org/0000-0002-0177-1101

Doctoral student in Business Administration at Federal University of Bahia (UFBA); Master of Business Administration from Pontifical Catholic University of São Paulo (PUC-SP); Postgraduate in marketing from College of Advertising and Marketing (ESPM-SP); Specialization in marketing from Bocconi University; Professor of postgraduate courses in marketing, Salvador-BA, Brazil. E-mail: grimaldilarocca@gmail.com

\section{Rodrigo Ladeira}

ORCID: https://orcid.org/0000-0001-8243-7270

Doctor in Business Administration from Faculty of Economics and Administration, University of São Paulo (FEA-USP); Post-Doctorate from Stern- New York University; Associate Professor II at School of Administration from Federal University of Bahia (UFBA); Permanent Professor of Postgraduate Nucleus of the School of Administration of the Federal University of Bahia (NPGA-EAUFBA); Coordinator of the Research Group in Contemporary Marketing, Salvador-BA, Brazil. E-mail: rodladeira@yahoo.com

Áurio Lúcio Leocádio da Silva

ORCID: https://orcid.org/0000.0003.3175.3382

Doctor in Administration from Faculty of Economics and Administration, University of São Paulo (FEA-USP); Adjunct Professor IV of the Federal University of Ceará at Administration Department (UFC-FEAAC); Permanent Professor of the Administration and Controllership Program (PPAC-UFC); Coordinator of the Research Group Strategy for Sustainable Society (LESS), Fortaleza - Ceará, Brazil. E-mail: aurioleocadio42@gmail.com

\section{Ricardo Coutinho Mello}

ORCID: https://orcid.org/0000-0002-3265-6595

Doctor in Knowledge Diffusion at Federal University of Bahia (UFBA); Adjunct Professor III at Federal University of Bahia from School of Administration (UFBA), Salvador - BA, Brazil. E-mail: rcmello@ufba.br 